\title{
The EU-Africa summit 2021 \\ Quo vadis, in the light of Brexit and Corona?
}

\author{
Dirk Kohnert ${ }^{1}$
}

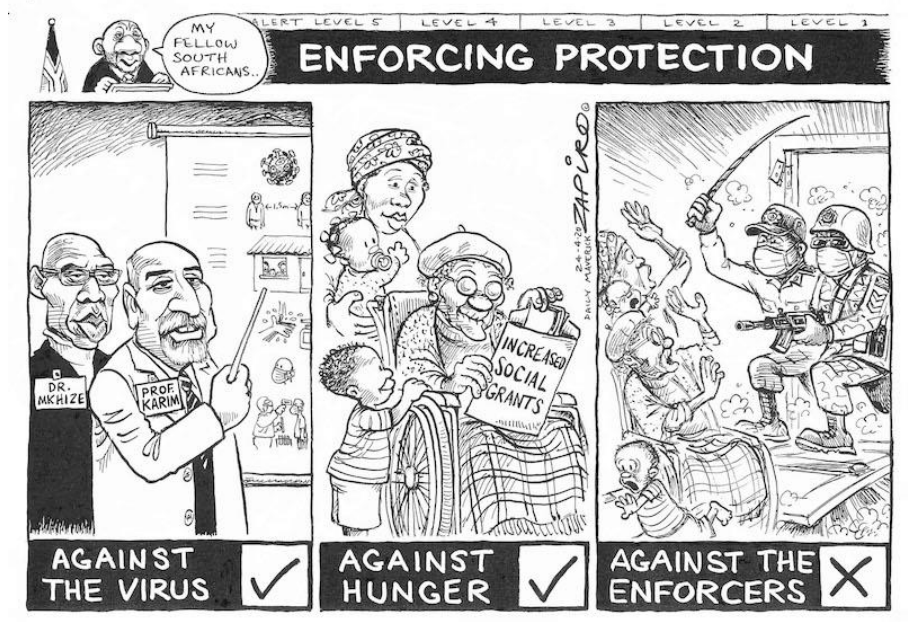

,Enforcing Protection`

Source: Zapiro, Daily Maverick, 24 April 2020

\begin{abstract}
Every three years, the AU-EU summit reunites African and EU leaders to outline the future direction of cooperation. The 6th summit had been to reaffirm and renew the partnership between the two blocks already in October 2020, but it was pushed back to the first quarter of 2021 or even later due to COVID-19 crisis. Besides, Brussels had to deal with its own postBrexit situation and its repercussions on EU-Africa relations, excluding the UK. African states, for their part, wanted to renegotiate the EU-Africa partnership and to balance it with new promising Post-Brexit visions of the British premier Johnson about increased economic ties with the African Angloshere. China and other global players compete with the EU and its member states in the new scramble for African resources. Given that Africa is increasingly courted by other partners it could be inclined to successively limit its relations with the EU and see it as a mere provider of aid and security against Islamic terrorism. This trend was reinforced by the fact that the new EU-Africa strategy still hasn't been approved by EU member states. And a timely replacement of the Cotonou Agreement, which expires in November 2021, is open to question.
\end{abstract}

Keywords: Corona, Brexit, Africa, UK, EU, international trade, economic recession, poverty, violence

JEL-Code: F13, F35, F54, F63, G15, I1, N17, N47, N67, O17, P16, Z13

\footnotetext{
${ }^{1}$ Associated expert at the Institute of African Affairs, German Institute for Global and Area Studies, Hamburg. Draft: 14 March 2021.
} 


\section{Introduction}

Every three years, the AU-EU summit reunites African and EU leaders, alternating between headquarters in Africa and Europe, to outline the future direction of cooperation. The $6^{\text {th }}$ summit had been to reaffirm and renew the partnership between the two blocks already in October 2020 under German chairship of the EU-Council. However, due to COVID-19 crisis, it was pushed back to the first quarter of 2021 and later on adjourned to June 2021 (Hermenegildo \& Cunha, 2021). Because Germany handed over the EU Council Presidency to Portugal end of 2020, Portugal assumes the presidency of the EU council for the first halfyear. Meanwhile, it became even uncertain whether the summit would not have to be postponed another time, and it is open to doubt whether Slovenia that would chair the summit for the second half-year, could handle it with the same competence as the government in Lisbon, with its long-standing vested interest in African affairs. The following provides an upto-date overview of the relevant international discussion and literature on the topic.

Initially, the summit focused on renegotiating EU-African relations, including an agreement of the Organisation of African, Caribbean and Pacific States (OACPS; i.e. the former ACP member states) to replace the Cotonou agreement, signed in 2000 between the EU and 79 countries, including 48 African states, mostly former Britsh and French colonies ${ }^{2}$. However, the COVID-19 crisis upsets the agenda as well as the priorities of both partners. Besides, Brussels had to deal with its own post-Brexit situation and its repercussions on EU-Africa relations, excluding the UK. African states, for their part, wanted to renegotiate the EU-Africa partnership and to balance it with new promising Post-Brexit visions of the British premier Johnson about increased economic ties with the African Anglosphere.

Even though the overarching political framework for EU-Africa relations, the Joint Africa-EU Strategy (JAES), was formally adopted at the Lisbon Summit in 2007 by representatives of 53 African and 27 European states, and although negotiators reached a political agreement on a new post-Cotonou partnership agreement on December 3, 2020, the EU was unable to take advantage of the Covid crisis to underline the specificity of its relations with the African continent. It was even overtaken by China, which appeared to fly to Africa's rescue during the pandemic. The ineffectual support by the EU re-motivated the African Union (AU) to hurryup with the creation of the African Continental Free Trade Area (AfCFTA) which should enable it to negotiate partnerships at eye-level with others around the world. Given that Africa is increasingly courted by other partners it could be inclined to successively limit its relations with the EU and see it as a mere provider of aid and security against Islamic terrorism.

This trend was certainly reinforced by the fact that the new EU-Africa strategy still hasn't been approved by EU member states. Moreover, a timely replacement for the Cotonou Agreement, which expires latest in November 2021, is open to question ${ }^{3}$. Although

\footnotetext{
${ }^{2}$ The OACPs Agreement will still have to be approved, signed and ratified by the parties concerned. It will cover a large number of areas, ranging from sustainable development and growth, to human rights and peace and security and will be geared to empower each region. Once in effect, the Agreement will serve as the new legal framework and guide political, economic and cooperation relations between the EU and 79 members of the OACPS for the next twenty years. The application of the old Cotonou Agreement will be further extended until 30 November 2021, unless the new agreement enters into force or is provisionally applied before that date. European Commission, Brussels, 3 December 2020.

${ }^{3}$ EU (2021): After Cotonou: Towards a new agreement with the African, Caribbean and Pacific states. Brussels: European Parliament, Briefing - International Agreements in progress. - "The EU is very much preoccupied with itself — partly due to the COVID-19 crisis," said Mathias Mogge from VENRO, an umbrella organization for development NGOs in Germany. "Partnerships with Africa have since faded into the background." (Pelz, Daniel (2020): Africa-Europe relations: 2020 was a lost year. DW, 20.11.2020).
} 
cooperation with Africa gained in importance in the EU in the face of migration policy and increasing economic and geopolitical competition with China, Russia and other actors, the notions of equality and shared ownership, that had been so central to the JAES at its inception, remained more of a vision than a reality, with much of the continental relationship still heavily reliant on post-colonial ties and EU-donated money (Kell \& Vines, 2020).

The following incident is indicative of the fact that the European negotiators have apparently slept through the signs of the times. In view of the corona crisis, the heads of state and government of the EU and the AU had agreed to hold the summit by means of a video conference at the beginning of December 2020. However, the African side canceled at the last minute due to differences on agenda issues. Provocative remarks by two French medical experts in spring 2020 were largely responsible for this. The latter came up in the context of African complaints about the current and historical treatment of African countries and officials, including on health issues. Statements by the French experts on a possible study in Africa on the effects of a tuberculosis vaccine in combating the coronavirus suggested for the African side that Africans could also be used as "test guinea pigs" with regard to the corona vaccine (Herszenhorn, 2021). In fact, testing new drugs on Africans was common practice at European drug companies from colonial times until the 2000s (Flint, 2021; Rottenburg, 2009). This explains the reservations of African doctors and politicians and the demand for fairer international relations between Europe and Africa, including access to vaccines against corona and other drugs (Flint, 2021).

\section{The new scramble for Africa's resources}

A strong indicator of a new scramble for Africa was the multitude of Africa summits all over the world. This concerns not just the EU-Africa- and the competing Post-Brexit UK-Africa summit 2020, but also the China-Africa summit on COVID-19 of June 2020, the 2018 Beijing Summit of the Forum on China-Africa Cooperation, the 'Africa-France summit 2020 ', the 'Middle East-Africa summit 2020', the 'Turkey- Africa summit 2020', the 'Forum on ChinaAfrica Cooperation (FOCAC) 2021', the 'Russian-Africa-Summit 2019' and the 'Russia-Africa summit and Economic forum 2022' (Soulé, 2020). African leaders used these platforms not only as an opportunity for their image cultivation or to attract investments but also as a means to exert more agency at the domestic policy level. Their strategies were inspired by four main targets:

(1) Attract investment in a competitive international political environment by outmanoeuvring their partners in applying the sea-saw policy effectively proven already in times of cold war

(2) Diversify economic and political partners to reduce dependency

(3) Claim back their economic policy space, and

(4) Escape from political isolation by getting more visibility and expanding networks (Soulé, 2020).

The conventional focus of political science on traditional and emerging powers rivalry on the continent diverted African actors from investigating their own motives and strategies for choosing their partners. Therefore, a partisan scholarly analysis should put African agency back at the centre and evaluate Africans as key agents of the decision-making process (Soulé, 2020). 


\section{Mayor issues of the EU-Africa summit}

Therefore, a complete reset of the paternalistic EU partnership-talk is overdue. Apart from the traditional focus on global transformations, the historical shift from the (post-)colonial EuroAtlantic to the Asia-Pacific zone, as well a rising trend toward multipolarity and deepening interdependence among countries, there are more pressing immediate needs at stake in the coming post-Covid-19 years. They will require also enhanced policy effectiveness and most notably, partnership on equal footing with result-oriented procedures, including monitoring and evaluation (Kaul, 2020).

Although there remain still many open questions, what is certain is that African actors do not want anymore to be outmanoeuvred according to the usual divide and conquer strategy of the former colonial powers. Instead, they are increasingly in favour of a 'continent to continent' partnership with the EU, thus capitalizing on the AUs 'Agenda 2063', i.e. the blueprint to transform Africa into a global power (Forysinski \& Emmanuel, 2020).

Thus, coping with the Corona crisis will shape the cooperation between the EU and Africa for the years and decades to come. It will significantly inform and structure also the EU - Africa migration and development policy against the background of increasing geopolitical and economic competition with China, the USA, Russia and other global actors.

The European Commission, together with the European External Action Service, launched a Joint Communication to the European Parliament and the Council on a new EU-Africa Strategy in March 2020. It addresses five separate partnerships, in line with the priorities, which will serve as a basis for further discussions at the $6^{\text {th }}$ EU-Africa Summit in 2021 (UNIDO, 2020):

(1) A partnership for green Transition and Energy Access

(2) A partnership for digital Transformation

(3) A partnership for Sustainable Growth and Jobs

(4) A partnership for Peace and Governance

(5) A partnership on Migration and Mobility

Additional crucial points on the agenda of the coming EU-Africa summit should include:

- The AUs 'Agenda 2063' - how to make it a game-changer?

- How can the EU contribute to making the African Continental Free Trade Area (AfCFTA) work?

- What role for cooperation on international climate policy?

- What role of a European-African Green Deal?

- What role for cooperation on energy transition?

- Agenda for an AU-EU partnership for investment

- Towards a digital partnership between the EU and the AU, concerning National Policy-Makers, Entrepreneurs, innovators, and investors, academia and think tanks, and international organisations ${ }^{4}$ (DIE, 2020).

\footnotetext{
${ }^{4}$ The proposed webinars and policy papers were jointly developed by the DIE (Bonn), the African Center for Economic Transformation (ACET, Accra), the European Centre for Development Policy and Management (ECDPM, Brussels) and the European Think Tanks Group (ETTG). The rationale behind it is to bring together African and European decision-makers, academics and representatives of the private sector and civil society to identify convergences of interest, to develop common solutions and opportunities for cooperation (DIE, 2020).
} 


\section{Democracy and Human Rights promotion}

The Human Rights issue, pushed hitherto by the EU in its relations with Africa, in stark contrast to China-Africa relations, becomes especially tricky because of its possible infliction with issues of sovereignty and African agency. Finally, it is for African leaders themselves to decide, whether 'restrictive measures', as applied in the past by the EU, e.g. concerning the much-criticised attendance of some of the most notorious (i.e. corrupt or human rightsabusing) African leaders such as Omar al Bashir (Sudan), Eyadema Gnassingbé (Togo) and Robert Mugabe (Zimbabwe) are still topical. Up to now, the EU applied a pragmatic approach by including, rather than sanctioning and excluding, these leaders from EU-Africa summits (Wyk, 2018). However, each element of the 'restrictive measures' invariably influences both partners, although not necessarily in the same manner or to the same effect, because they are intertwined and influence each other (Kotsopoulos \& Mattheis, 2018). These entanglements constitute a framework that could be used to recalibrate African and European perspectives.

Closely connected is the role of civil society actors (CSA) in the EU-Africa relationship. However, this would require to reflect on the concept of CSA with due consideration of its European origins and how common descriptive parameters for understanding the concept of civil society in the EU-Africa context can be discerned by understanding, appreciating and eventually re-defining the concept by applying the African gaze with due consideration of the impact of Corona crisis and EU-Post-Brexit issues as a blueprint for the future (Madu, 2020).

To recognise the potential weight of non-state actors, including business associations and corporate actors, in shaping the contours of economic globalisation, including interstate power relations and respect of sovereignties has become mandatory under the impact of COVID-19. Thus, the new scramble for Africa's resources should be restricted by due regard to sustainable development, sovereignty and the possible revival of neo-colonialism in Africa, both north and south of the Sahara (Langan \& Price, 2020).

\section{Peace and security in the context of EU-Africa relations}

The EU's role in the context of Africa's peace and security architecture is complex. The EU acquired a broader perspective of peace and security than other global players who are interested in African affairs. European visions went beyond military security and combat of Islamist terrorism. They included human and environmental security as well as migration issues. Inevitably, this affects also African agency and postcolonality (Steager \& Gwatiwa, 2020). Thus, the EU and its member states, notably France as former colonial power with vested interests in the so-called 'France-Afrique', advocated mixing security with development and institution-building to the benefit of African citizens and democratization. This European vision substantiates in a more holistic approach, implemented for example as the EU's 2013 Comprehensive Approach to External Conflict and Crises, the 2016 Global strategy (Global strategy for the foreign and security policy of the European Union), and the $2017 \mathrm{New}$ European Consensus on Development (Steager \& Gwatiwa, 2020). It draws heavily from the UN policy and was particularly promoted by Western governments in the early 2000s, prescribing increasing interlinkages between development and security to the mutual benefit of European and African actors. The UN also helped to foster close cooperation between European and African partners, especially in security matters (Steager \& Gwatiwa, 2020). 
However, for the AU, the mantra of an African solution to African problems served more often than not as an excuse in order to shelve inconvenient solutions of conflicting problems down to the wire.

\section{Regional integration:}

The promotion of regional integration constitutes a joint aim of EU and Africa relations for decades. The AUs 'Agenda 2063' gave it an additional boost because it defined regional integration as a necessary first step to a common African Continental Free Trade Area (AfCFTA; Piccolino, 2020; Kohnert, 2019). The Corona-crisis severely impacted on regional integration too, because any failure to contain the virus in one country ultimately threatens the safety of others. This calls for a coordinated response across countries by African Regional Economic Communities (RECs), like the ECOWAS, WAEMU, COMESA and SADC in shaping collective, coordinated regional responses. Apparently, the AU had been able to inspire collective action in a unified call for international solidarity (Medinilla \& Byiers \& Apiko, 2020). At the regional level, responses to the Corona-crisis reflect a broad spectrum of cooperation, ranging from information sharing to active coordination of state responses and collective actions. The performance of different RECs depended last, but not least, on their regional and institutional histories, structural features such as the size and coherence of the REC, as well as the political economy dynamics of the countries in its region. At least in West Africa state and civil society actors profited also from past experience with the handling of the West African Ebola epidemic (Medinilla \& Byiers \& Apiko, 2020).

\section{Need for a new EU-Africa employment pact}

Moreover, there exists the need for a new EU-African employment pact (Rauch, 2021). Jobs in Africa need fair trade conditions combined with employment-oriented industrial policy and coordinated initiatives by local actors, embedded in the political, economic and health framework of their respective region and its degree of infection by COVID-19. Here again, a cross-country regional approach is imperative, because the virus does not take account of frontiers. This includes a humane immigration policy because African migration will probably even increase under the economic impact of the Corona-crisis on Africa. Strategies for common African-European migration policies should take into account both: on the one hand, the ongoing economic need for existence in large parts of Africa and the resulting efforts to build up translocal (if necessary also intercontinental) survival systems. On the other hand, a sustainable migration policy must be drawn up jointly, based on a balance of interests. Important cornerstones of EU-African migration agreements should be: (1) combating the causes of migration, (2) creating legal access routes, including circular migration, even for low-skilled workers, to temporary employment opportunities, and (3) return guarantees for irregular immigrants (Rauch, 2020).

\section{Need for a common environmental and agricultural policy}

Climate change and its impact on the population, policy, economy and environment have become increasingly central to EU-African relations too. African agency is marked by the rise of increasingly vocal green actors (Lightfoot, 2020). However, the priorities of the latter, e.g. of the African Union (AU), are not necessarily the same as those promoted by the EU, 
especially via the Joint Africa-EU Strategy, adopted during the $2^{\text {nd }}$ EU-Africa summit 2007 in Lisbon. Current European approaches reflect a broader power imbalance within African-EU relations because the rules that frame the relationship reflect those of the EU.

The future dialogue on eye-level could offer opportunities for new state and non-state actors in Africa which again will impact also on the strategy of the EU. Closely related is the need for a new agricultural and land policy in EU-African relations, far beyond the long-standing scramble for African resources. Resource extraction, based on widespread dispossession and exploitation of the African population, had been at the heart of relations between Europe and Africa since the advent of European colonialism, the influence of which endures to the present day (Lahiff, 2020).

According to Robert Kappel (2020), two major negotiation processes of the EU with Africa are pending: First, a Comprehensive Strategy for Africa (CSA), and second, a replacement of the Cotonou Agreement which expires in November 2021 (see above). However, the CSA has conceptual weaknesses. Not only because European interests are only vaguely worded. It does not state clearly whether it is about geostrategic action towards China, the USA and emerging economies, whether the EU just want to promote European investments, or contribute to climate change, or help to eradicate poverty and unemployment. The CSA is rather a bundle of visions that range from digitization, green economy to trade issues without integrating them into a strategy. Therefore the CSA needs to be revised significantly, taking into due account that African countries and their institutions are pursuing their own agenda and that global power shifts are recognized (see above). Issues should not be restricted to financial flows, restructuring trade, resolving crises and pandemics, the combat of terrorism or good governance. It is about a fundamental change of direction that ends the traditional dependency between Europe and Africa. Thus, European commitment should focus on new subject areas, clearly different from the geostrategic actions of China, Russia, USA and other emerging countries in the new scramble for Africa, i.e.:

(1) New agricultural policy,

(2) Support for transformation processes,

(3) Linking foreign direct investments with local entrepreneurship.

(4) reorientation of trade relations,

(5) Debt relief and restructuring of the CFA zone.

\section{Impact of Brexit on EU-Africa relations}

High-flying illusions on the part of the proponents, and grim predictions on the part of the sceptics have characterised the controversy around Brexit. The five key issues at stake for post-Brexit relationships between Britain, the EU, and Africa are as follows: market access, foreign direct investment (FDI), aid, security, and the nature of the partnership. The British government's vision of a "Global Britain" relies heavily on its reinforced cooperation with Commonwealth nations, last, but not least in the African Anglosphere (Gamble, 2021; McDougall, 2019; Wellings, 2019). The Anglosphere belongs in a long line of thinking about uniting English speaking communities around the world. The Anglosphere appeals to many Brexiters because it gives them a positive vision of 'Global Britain' as an alternative to EU membership. Yet, what is ignored, is the lack of support among African Anglosphere countries for much closer relationships except in the security sphere, and the inability of increased economic ties to match what the UK will lose by severing itself from its most important economic partner, the EU. Therefore, the expectations of Brexiteers and African 
politicians alike concerning an enhanced, partnership-like post-Brexit Commonwealth relationship are largely unfounded. Although the post-Brexit United Kingdom will increase African countries' choices regarding preferred trading partners, it remains questionable whether London could offer something new that other global players with increasing interest in Africa, such as China, do not already have on their agenda. (Kohnert, 2018).

Moreover, there are additional consequences of Brexit for Africa, even a revitalisation of the corrupt, murky French network, known as Françafrique, developing and expanding across the continent, can not be excluded (Kohnert, 2019). Whereas the impact of Brexit on Anglophone Africa was a major issue in the controversial British discussions on the pros and cons of Brexit, possible repercussions on French-speaking Africa had been rarely mentioned. At most indirect general effects were declared, both concerning the former British Empire in Africa and for the former French colonies as well. On the other hand, British Brexiteers have not tired of yearning for the re-establishment of the so-called glory of the British Empire, conceivably based on a euphoric and over-ambitious multi-expert report of the UK's Africa All-Party Parliamentary Group (APPG, London), financed by the Royal Africa Society, on the post-Brexit Africa-UK trade and development cooperation relations. Although the empire of so-called 'Françafrique' has been out-matched by British dominance in Africa, it is still very much alive today. It is an integrated political, military, economic and financial system of venality across the continent by which French and African political and business elites scratch each other's backs at the expense of their citizens. It is walled-off by a special currency, the CFA franc, assured restricted competition and extraordinary gains for all parties involved. Thus, post-colonial dependence continued, including the looting of raw materials, with the complicity of corrupt African heads of state, sometimes maintained at great expense, but also aware of their power over the former metropolis. Examples are the escapades of infamous 'emperor' Bokassa of the Central African Republic in the 1970s, or the pillage of the resources over decades by late Omar Bongo in Gabon (succeeded after his death in 2009 by his son Ali Bongo) and general Eyadéma Ganssingbé of Togo, continued by the heir to his throne, Faure Gnassingbé, who is still in power. In the context of the lack of the countervailing power of Britain within the EU in the case of Brexit, the murky network of Françafrique or alternative shady networks of corruption, trafficking and money-laundering in Francophone Africa could become re-vitalized and consolidated, notably in the resource-rich countries like the Democratic Republic of Congo.

However, Brexit could also inspire Africa in re-launching a debate on its sovereignty, including judicial and monetary issues. For example, concerning the long-standing controversy on the ill-adapted and increasingly anachronistic CFA franc. In fact, the debate has already begun. This has been assisted by internationally renowned African officials and critics of the CFA franc, including Togo's Kako Nubukpo (previous head of the Central Bank

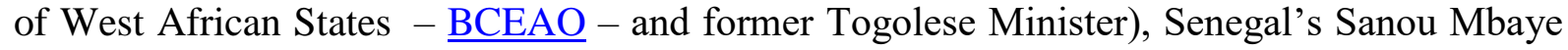
(formerly a senior official at the African Development Bank), and Guinea-Bissau's Carlos Lopez (formerly executive secretary of the UN Economic Commission for Africa), as well as African bankers like Henri-Claude Oyima (President-Director General of BGFI Bank). Besides, for some years, a social movement has developed to demand the withdrawal of African states from the CFA. On 7 January 2017, for example, an NGO set-up and run by the activist Kemi Séba, backed by 'SOS Pan-Africa', organised anti-CFA demonstrations in several African and European cities. In Senegal, the France Dégage group has been campaigning for the 'monetary sovereignty' of the CFA countries. On 20 May 2020, France adopted a bill according to which the BCEAO managing the currency of the eight nations of the WAEMU (UEMOA) which use the West African CFA franc, will no longer be required to deposit half of its exchange reserves with the Public Treasury of France. Furthermore, the 
French government would withdraw from all governing bodies of the BCEA. This was the second step towards the disappearance of the CFA franc and its replacement by a single currency called Eco.

\section{The impact of Corona-pandemic on EU-Africa relations}

The key challenges that the EU faces concerning the Corona pandemic are the close link between internal unity and cohesion and the ability to project power globally. The EU can only credibly undertake systemic rivalry with countries like China and Russia if it can defend its own values within its own boundaries. The pandemic has, moreover, underlined that the EU needs to work on its strategic sovereignty and that its global leadership is now needed more than ever (Koenig \& Stahl, 2020). The EU external action tends to become more cohesive and effective beyond the early phases of crisis response. Comparing the handling of the crisis with Eu competitors like the US, China, Russia and other global players, shows that the EU's enhanced structural, regulatory, and normative power will probably be needed too in the global aftermath of this crisis. This concerns for example increasing investments in research and development, active science diplomacy and fast, but also sustainable reactions in the field of development cooperation that include long-term goals for social, ecological and economic recovery after the crisis, and an improved information policy with stronger public relations so that the EU can reliably maintain its position as the most important and partnership-oriented partner for Africa (Brugner \& Schuch, 2020).

Covid-19 offers a new opportunity for the EU to establish a more balanced and pragmatic partnership with Africa, serving their joint interests. In particular, both partners will have to define new engagement mechanisms that involve also the private sector and civil society (Jaidi, 2020). Yet, the main challenge will be for the partners to find a way to address these issues effectively and united, despite the political cleavages and tensions caused by conflict and fragility, still enhanced by the pandemic. Crises, such as combatting Islamist terrorism in the Sahel, the Horn of Africa crises and the warlord's battles in Libya, or the economic and financial fallout from Covid-19, created divisions that could complicate the outcome of the partnership processes. It is not unlikely that the concerns of the major players like France, Russia, Turkey, or second-tier regional actors, will dominate the agenda of Euro-African relations (Jaidi, 2020). However, the Covid-19 crisis also offers an opportunity to think and act differently, e.g. concerning human security and regional solidarity between the two continents. The persistence of the pandemic further underlines the interdependence of vulnerabilities and the need for a rigorous, comprehensive and sustainable partnership framework. In addition to health and humanitarian concerns, many have expressed fears for the stability, state consolidation and security of Africa. Covid-19 pandemic calls for a different set of reactions than usual. The long-term aspects of the crisis require a policy of resilience beyond immediate measures of economic, social or financial support (Jaidi, 2020). Mandatory is a united and sustainable approach. Any failure to contain the virus in one continent or country ultimately threatens the safety of others (Medinilla \& Byiers \& Apiko, 2020).

\section{Competing principal players: the China effect}


The rise of populism in Europe, illegal migration from Africa to Europe and growing notions in Africa of a condescending Europe make for a fundamental change in EU-Africa relations in which the global order is contested, and fundamental principles are being challenged (Hodzi, 2020). Africa is using bourgeoning relations with China to increase its power and to demand equality. Perceptions of competition and rivalry between China and the EU by African leaders increase their bargaining leverage in negotiations with the EU.

Chinese aid and political and economic cooperation are based on non-interference as well as the respect of African sovereignty. Apart from that, Peking tends to mix commercial interests with concessional flows, in a demand-driven aid allocation process that often translate into local aid impacts that differ from those of European donors (Isaksson \& Kotsadam, 2021). The muddling of concessional finance with other financial flows makes it difficult to distinguish between commercial gain and development aid. Most often than not, Chinese projects tend to embrace both. However, the Chinese request-based aid system also provides opportunities for recipient countries to channel aid strategically by distributing funds locally in favour of their patronage network. Voters may reward incumbent leaders who locate aid to their home area. If thus ethnic or local voters are mobilized in the political power play, the competition for the inflow of aid could mobilize ethnic identities everywhere. Perceived or real ethnic bias in aid-delivery may givee rise to ethnic grievances, fierce competition and social unrest. Moreover, it is likely to fuel local corruption and to discourage trade union involvement (Isaksson \& Kotsadam, 2021).

Thus, the EU is bound to adapt its own Africa policies to guard whatever goodwill it had acquired there (Babarinde, 2020). The Joint Africa-Europe Strategy constitutes the framework for development, based on a neo-liberal and neo-realistic discourse to explain the enduring relationship. Nevertheless, the relationship between the EU and Africa is still profoundly asymmetrical, notwithstanding the EU's rhetoric of development policies toward Africa that are positioned somewhere between its normative ideals and the realities of competing emerging alternative frameworks (Babarinde, 2020).

Thus, the impact of China's engagement in Africa on EU-Africa relations seems more relevant than ever. China's „One Belt, One Road“ initiative (OBOR) or 'silk road'-initiative, including the maritime silk road, is supposed to go past the coast of East Africa, where several ports are being built and will be built. Moreover, branches are not only constructed on the maritime silk road's direct way along Africa's East coast through Suez Canal but also on coasts of Central Africa up to the Golf of Benin in Western Africa (Schwerbrock, 2017; Breuer, 2017). There, Chinese trade-hubs are constructed for the collection of raw materials and the distribution of goods made in China also as access-routes to the interior of landlocked African states, like the deep-water harbour of Togo, a historically close ally of China. Some of those ports are planned to be connected to Africa's hinterland by Chinese built roads and railways, thus constructing even a second Chinese belt on the African continent. In short, the 'One Belt, One Road' initiative is thus not only about Eurasia, but also to a significant extent about Africa.

\section{Conclusion}

In international relations, the EU-Africa relations occupy a unique position because of the shared colonial history of both partners and the resulting common roots of culture and society. This concerns, last but not least, a common official language, including the language divide between Anglophone and Francophone Africa. On the one hand, this constitutes a unique 
selling point and competitive differentiator vis à vis other global players, like China, the US and Russia. Therefore, the comparison of the EU-Africa summit with other Africa summits of non-EU countries is only of limited value. On the other hand, the complexity of political regimes in Africa favoured core political behaviours of African leaders, perceived as a specific expression of African agency in global politics that could enhance their weak power in global politics, i.e. forum-shopping, regime-shifting and strategic manipulation of values (Suh I, 2020).

Thus, Africa, increasingly courted by other partners, could be inclined to successively limit its relations with the EU and see Europeans as a mere provider of aid and security against Islamic terrorism. However, the potential for enhanced EU-Africa relations is limited by the 'path-dependency' in which both partners remain largely trapped (Bossuyt, 2017). External events, like the Brexit and the resulting break-away of the UK from the EU, now constituting itself as a competing actor in African affairs, as well as the Corona-crisis could offer new perspectives to get out of this trap in building 'pathways to change'. However, it would be unrealistic to expect these changes to realize in a short-time because the new EU-Africa strategy still hasn't been approved by EU member states, and a timely replacement of the Cotonou Agreement, which expires in November 2021, is open to question.

\section{References}

Babarinde, Olufemi (2020): New directions in EU-Africa development initiatives. in: Beringer, Sarah L. \& Sylvia Maier \& Markus Thiel (eds.): EU development policies between norms and geopolitics. London: Springer, International Political Economy Series book series (IPES), pp. 111134

Breuer, Julia (2017): Two belts, one road ? The role of Africa in China's belt \& road initiative. Blickwechsel, July 2017: 1-8

Brugner, Philipp \& Klaus Schuch (2020): The EU's global response to the COVID-19 crisis with a focus on the Eastern Neighbourhood and Africa. Vienna: Österreichische Gesellschaft für Europapolitik, 03 June 2020

Bossuyt, J. (2017): Can EU-Africa relations be deepened? A political economy perspective on power relations, interests and incentives. Brussels: ecdpm, Briefing Note 97

Derek McDougall (2019) English Nationalism, Brexit and the Anglosphere:Wider Still and Wider, The Round Table, 108:6, 725-727 ---- Review of: Wellings, Ben (2019) English Nationalism, Brexit and the Anglosphere:Wider Still and Wider. Manchester: Manchester University Press, 2019, ix +205 p

Flint, Karen (2021): "Africa Isn't a Testing Lab": Considering COVID Vaccine Trials in a History of Biomedical Experimentation and Abuse. Journal of West African History, Vol. 6, Number 2, Fall 2020: $126-140$

Forysinski, W. \& A. Emmanuel (2020): EU-Africa relations - Towards a new comprehensive strategy with Africa. Between a rock an a hard place. Przeglad Strategiczny, 2020.13: 61-78

Gamble, Andrew (2021): The Brexit negotiations and the Anglosphere. The Political Quarterly, 04 January, 2021, online

Hermenegildo, R.S. \& Alice Cunha (2021): Portugal and the 2021 counil preidency: an unambitious programme? Brussels: Trans-European Policy Studies Association, TEPSA-Briefs, January 2021, pp. 1-3

Herszenhorn, David M. (2021): Charles Michel: EU-Africa summit still up in the air. Politico, January 5,2021 
Hodzi, Obert (2020): The China effect - African agency, derivative power and renegotiation of EUAfrica relations. In: Haastrup, Toni \& Niall Duggan \& Luís Mah (eds.): The Routledge handbook of EU-Africa relations, London: Routledge, 1st ed., Dec. 31, 2020, pp. 256-265

Isaksson, Ann-Sofie \& Andreas Kotsadam (2021): Chinese Aid to Africa: Distinguishing Features and Local Effects. Munich: cesifo-Forum, 2.2020, Focus: How can Europe better contribute to Africa's economic transformation in a post-Corona era?, July 2020, vol. 21, pp. 27-31

Jaidi, Larabi (2020): The challenges of Euro-African relations in the post-Covid-19 era. Rabat: Policy Center for the New South

Kaul, Inge (2020): Want to Take the Africa-EU Partnership to the Next Level? Press the Reset Button. Munich: cesifo-Forum, 2.2020, Focus: How can Europe better contribute to Africa's economic transformation in a post-Corona era?, July 2020, vol. 21, pp. 16-21

Kappel, Robert (2020): Zusammenarbeit Afrika-Europa: Die Chancen zur Neuorientierung nutzen. (blog)

Keijzer, Niels, \& Alfonso Medinilla (2017): Can the EU prioritise both the African Union and the Africa, Caribbean and Pacific group? European Think Tanks Group, Brussels: ECDPM, November 2017

Kell, Fergus \& Alex Vines (2020): The evolution of the Joint Africa- EU Strategy (2007-2020). In: Haastrup, Toni \& Niall Duggan \& Luís Mah (eds.): The Routledge handbook of EU-Africa relations, London: Routledge, 1 st ed., Dec. 31, 2020, pp. 105- 120

Köhler, Horst (2020): Crisis and credibility - Towards new honesty in EU-Africa relations. CESifo Forum, München, ifo Institut, Vol. 21, Iss. 02, pp. 11-15

Koenig, Nicole \& Anna Stahl (2020): How the coronavirus pandemic affects the EU's geopolitical agenda. Hertie School, Jacques Delors Centre, IPolicy Paper, 24 April 2020

Kohnert, Dirk (2019a): Brexit and the Revival of Françafrique. ROAPE-blog. London: Review of African Political Economy (ROAPE), 19 June 2019

Kohnert, Dirk (2019): The ethics of African regional and continental integration. MPRA WP, No.95562

Kohnert, Dirk (2018): More equitable British post-Brexit Africa relations: doomed to fail?, Africa Spectrum, vol. 53., No. 2, pp. 119-130

Kotsopoulos, John \& Frank Mattheis (2018): A contextualisation of EU-Africa relations: Trends and drivers from a reciprocal perspective, South African Journal of International Affairs, 25:4, 445-460

Lahiff, Edward (2020): Agriculture and land in EU-Africa relations. In: Haastrup, Toni \& Niall Duggan \& Luís Mah (eds.): The Routledge handbook of EU-Africa relations, London: Routledge, 1st ed., Dec. 31, 2020, pp. 336-348

Lightfoot, Simon (2020): Environment and climate change in the context of EU-Africa relations. In: Haastrup, Toni \& Niall Duggan \& Luís Mah (eds.): The Routledge handbook of EU-Africa relations, London: Routledge, 1st ed., Dec. 31, 2020, pp. 314 -323

Madu, Uzoamaka (2020): The role of civil society in EU- Africa relations . In: Haastrup, Toni \& Niall Duggan \& Luís Mah (eds.): The Routledge handbook of EU-Africa relations, London: Routledge, 1st ed., Dec. 31, 2020, pp. 324-335

Maurice, Paul (2021): Presidence Allemande du Conseil de l'UE : Quel bilan geopolitique ?, GéopoWeb.fr, 4 février 2021. Paul Maurice is research fellow at the Comité d'études des relations franco-allemandes.

Medinilla, Alfonso \& Bruce Byiers \& Philomena Apiko (2020): African regional responses to COVID-19. Brussels: ecdpm, DP No. 272, May 2020 
Pelz, Daniel (2020): Africa-Europe relations: 2020 was a lost year. Bonn: DW, 20.11.2020

Piccolino, Giulia (2020): Regional integration. In: Haastrup, Toni \& Niall Duggan \& Luís Mah (eds.): The Routledge handbook of EU-Africa relations, London: Routledge, 1st ed., Dec. 31, 2020, pp. $188-201$

Langan, Mark \& Sophia Price (2020): Toward a post-Westphalian turn in Africa-EU studies? Nonstate actors and sustainable development. In: Haastrup, Toni \& Niall Duggan \& Luís Mah (eds.): The Routledge handbook of EU-Africa relations, London: Routledge, 1st ed., Dec. 31, 2020, pp. 282-292

Rauch, Theo (2021): Für einen afrikanisch-europäischen Beschäftigungspakt. (blog) Weltneuvermessung,

Rauch, Theo (2020): Europäische Einwanderungspolitik: Jenseits von Zweckoptimismus und Panikmache (blog) Weltneuvermessung

Rottenburg, Richard (2009): Social and public experiments and new figurations of science and politics in postcolonial Africa, Postcolonial Studies, 12:4, 423-44

Schwerbrock, Julia (2017): Two Belts, One Road? The Role of Africa in China's Belt \& Road initiative. ResearchGate, July 2017

Soulé, Folashade (2020): 'Africa+1' summit diplomacy and the 'new scramble' narrative: Recentering African agency. African Affairs, Vol. 119, Issue 411, October 2020, pp. 633-646

Staeger, Ueli \& Tshepo T. Gwatiwa (2020): Peace and security in the context of EU-Africa relations. In: Haastrup, Toni \& Niall Duggan \& Luís Mah (eds.): The Routledge handbook of EU-Africa relations, London: Routledge, 1st ed., Dec. 31, 2020, pp.

Suh I, Norbert (2020): International Regime Complexity in EU-Africa Relations. The Journal of Territorial and Maritime Studies, Vol. 7, No. 2 (Summer / Fall 2020), pp. 27-48

UNIDO (2020): COVID-19 Impact on EU -Africa Relations. Brussels: UNIDO-Focus, June 2020

Wellings, B (2019): English Nationalism, Brexit and the Anglosphere: Wider Still and Wider (New Perspectives on the Right), Manchester University Press, 23. Mai 2019

Wyk, Jo-Ansie van (2018): Sanctions and summits: Sanctioned African leaders and EU-Africa summits. South African Journal of International Affairs, 2018, Vol. 25, No. 4, 497-515 
Résumé : Le Sommet UE-Afrique 2021: Quo vadis, compte tenu du Brexit et de la Covid-19?

Tous les trois ans, le sommet UA-UE réunit les dirigeants africains et européens pour définir l'orientation future de la coopération. Le 6e sommet devait réaffirmer et renouveler le partenariat entre les deux blocs déjà en octobre 2020, mais il a été repoussé au premier trimestre 2021, ou même plus tard, en raison de la crise du COVID-19. En outre, Bruxelles a dû faire face à sa propre situation post-Brexit, compte tenu l'exclusion du Royaume-Uni, et à ses répercussions sur les relations UE-Afrique. Les États africains, pour leur part, souhaitaient renégocier le partenariat UE-Afrique, et l'équilibrer avec les nouvelles visions post-Brexit prometteuses du Premier ministre britannique Johnson sur le renforcement des liens économiques avec l'Anglosphère africaine. La Chine et d'autres acteurs mondiaux sont en concurrence avec l'UE et ses États membre dans la nouvelle ruée vers les ressources africaines. Étant donné que l'Afrique est de plus en plus courtisée par d'autres partenaires, elle pourrait être encline à limiter successivement ses relations avec l'UE et à la considérer comme un simple fournisseur d'aide et de sécurité contre le terrorisme islamique. Cette tendance a été renforcée par le fait que la nouvelle stratégie UE-Afrique n'a toujours pas été approuvée par les États membres de l'UE. Et un remplacement opportun de l'accord de Cotonou, qui expire en novembre 2021, est sujet à caution.

Zusammenfassung : Der EU-Afrika Gipfel: Quo vadis, angesichts des Brexit und der Corona Krise?

Alle drei Jahre bringt der EU-Afrika Gipfel die Staats- und Regierungschefs Afrikas und der EU zusammen, um die künftige Richtung der Zusammenarbeit zu skizzieren. Das 6. Gipfeltreffen sollte bereits im Oktober 2020 die Partnerschaft zwischen den beiden Blöcken bekräftigen und erneuern, es wurde jedoch aufgrund der COVID-19-Krise auf das erste Quartal 2021 oder sogar auf später verschoben. Darüber hinaus musste sich Brüssel mit seiner eigenen Situation nach dem Brexit und dessen Auswirkungen auf die Beziehungen zwischen der EU und Afrika ohne Großbritannien auseinandersetzen. Die afrikanischen Staaten iherseits wollten die Partnerschaft zwischen der EU und Afrika neu verhandeln und sie mit neuen vielversprechenden Visionen des britischen Premierministers Johnson nach dem Brexit über verstärkte wirtschaftliche Beziehungen zur afrikanischen Anglosphäre in Einklang bringen. China und andere Global Player konkurrieren mit der EU und ihren Mitgliedstaaten im erneuten Kampf um afrikanische Ressourcen. Angesichts der Tatsache, dass Afrika zunehmend von anderen Partnern umworben wird, könnte es dazu neigen, seine Beziehungen zur EU sukzessive einzuschränken und die EU als bloßen Anbieter von Hilfe und Sicherheit gegen den islamischen Terrorismus zu betrachten. Dieser Trend wurde noch dadurch verstärkt, dass die neue EU-Afrika-Strategie von den EU-Mitgliedstaaten noch nicht gebilligt wurde. Ein rechtzeitiger Ersatz des Cotonou-Abkommens, das im November 2021 ausläuft, ist fraglich. 